\title{
Olga Poller
}

\section{Obrona deskrypcyjnej teorii odniesienia nazw Część I. Odpowiedź na argumenty Kripkego: modalny i epistemiczny}

In defence of a descriptive theory of reference for proper names Part I. A response to Kripke's modal and epistemic arguments

\section{Streszczenie}

W artykule tym bronię nieklasycznej deskrypcyjnej teorii odniesienia nazw własnych przed zarzutami Kripkego. Uważam, że informacja deskryptywna wiązana przez użytkowników z nazwą własną pełni funkcję semantyczną, dlatego nie może być pominięta w semantyce nazw. Nie bronię żadnej konkretnej wersji deskryptywizmu, tylko ogólnych założeń, w oparciu o które można zbudować różne rozwinięcia deskrypcyjnej teorii nazw. W pierwszej części artykułu przedstawię wyjaśnienie, czym jest deskryptywizm, wytłumaczę, w jaki sposób uwzględnianie parametru czasu wpływa na formułowanie tez deskryptywizmu, wytłumaczę też, dlaczego deskrypcyjnej teorii odniesienia nie dotyczy zarzut modalny, sformułuję tezy bronionej wersji deskryptywizmu oraz odpowiem na zarzut epistemiczny. W drugiej części artykułu (w następnym numerze) przedstawię odpowiedź na poszczególne wątki zarzutu semantycznego oraz pokażę, że broniona wersja ma zalety tradycyjnie przypisywane teoriom deskrypcyjnym.

Słowa kluczowe: deskrypcyjna teoria odniesienia nazw, nazwy własne, deskryptywizm, zarzut modalny Kripkego, zarzut epistemiczny Kripkego

\section{Summary}

In this article, I defend a non-classical version of descriptive theory of reference-fixing for proper names against objections raised 
by Kripke. I consider that descriptive information associated by speakers with a proper name has semantic value and thus should be taken into account by any theory of proper names. I do not defend any one descriptive theory in particular, only general assumptions that can underpin different elaborations of a descriptive theory of names. In the first part of this paper, I will briefly explain the notion of descriptivism and how taking temporal parameters into account influences the formulation of the theses of descriptivism. Next I will explain why Kripke's modal objection does not apply to a descriptive theory of reference-fixing, I formulate assumptions of the descriptive theory defended in this paper and respond to Kripke's epistemic objection. In the second part (to be published in the next issue), I respond to particular strands of Kripke's semantic objection and show that the defended version has all the virtues traditionally associated with descriptive theories.

Keywords: descriptive theory of reference, proper names, descriptivism, Kripke's modal argument, Kripke's epistemic argument

\section{Czym jest deskryptywizm}

Deskryptywizm jest stanowiskiem w sporze o semantykę nazw własnych, które zakłada klasyczne rozumienie znaczenia, czyli tezę w duchu Fregego, że informacja o obiekcie, którą wiążemy z wyrażeniem odnoszącym się, wyznacza semantycznie odniesienie tego wyrażenia, wpływa na wartość poznawczą oraz jest tym, czego dotyczą nastawienia sądzeniowe. Pierwsza teza klasycznego deskryptywizmu przedstawionego przez Kripkego (1980) dotyczy koniecznego i wystarczającego kryterium ustalania odniesienia nazwy i brzmi następująco ${ }^{1}$ :

1 Por. (Kripke 1980, s. 71, teza 3), (Cumming 2012, rozdział 2.3), (Salmon 2005, s. 12, definicja „Sense ${ }_{2}$ "), (Soames 2002, s. 5, definicja (ii)). 
1. Odniesienie nazwy własnej jest semantycznie ustalane poprzez spełnianie warunku deskryptywnego jakiejś (jakichś) deskrypcji określonej.

Druga teza dotyczy wiedzy mówiących, którzy posługują się nazwą. Teza ta brzmi:

2. Użytkownik zna nazwę wtedy i tylko wtedy, gdy zna deskrypcję określoną (-e), która ustala odniesienie nazwy własnej ${ }^{2}$.

Deskryptywizm w klasycznym rozumieniu zakłada obie te tezy: semantyczny sposób ustalania odniesienia nazwy, który jest znany i używany przez mówiącego, jest deskrypcyjny.

Tekst Kripkego Nazywanie a konieczność był skierowany przeciwko deskryptywizmowi i miał pokazać, że deskrypcje nie moga stanowić znaczenia nazwy (zarzut modalny i epistemiczny) oraz że użytkownicy nie posługują się deskrypcjami do ustalania odniesienia, a nawet moga w ogóle ich nie znać (argument semantyczny). Ale najważniejszym wnioskiem płynącym z jego tekstu była konieczność rezygnacji z rozumienia znaczenia jako utożsamienia semantycznego sposobu ustalania odniesienia (teza 1) ze sposobem, którym posługuje się mówiący (teza 2): konieczne i wystarczające kryterium ustalania odniesienia (mechanizm semantyczny) nie musi być nam znane i nie musimy korzystać z niego w codziennej praktyce językowej. Koniecznym i wystarczajacym kryterium ustalania odniesienia nazwy są według Kripkego łańcuchy przyczynowe - to one muszą zastąpić deskrypcje w tezie 1. Przykłady wskazujące na możliwości pomyłek i ignorancję miały pokazać, że kryterium z tezy 1 nie ma związku z wiedzą mówiącego (teza 2): nie musimy znać żadnego kryterium ustalania odniesienia,

2 Por. (Kripke 1980, s. 71, teza 1), (Burge 1977, s. 356, „Sense ${ }_{1}$ ), (Salmon 2005, s. 12, definicja „Sense ${ }_{1}{ }^{\prime)}$. 
by używać nazw i odnosić się do przedmiotów, a tego, co rzeczywiście ustala odniesienie (teza 1), możemy nie znać i, co więcej, nie korzystamy z tego w praktyce (por. Schroeter 2012, rozdz. 2.1).

Kripke sformułował tezy deskryptywizmu i zauważył, że w zależności od tego, jak odpowiemy na pytanie, co jest odniesieniem nazwy własnej z uwagi na możliwe światy, tezę 1 możemy rozumieć dwojako (1980, s. 57-58):

A. Odniesieniem nazwy własnej w świecie $w$ jest to odniesienie, które jest odniesieniem deskrypcji ustalającej(-ych) odniesienie nazwy w świecie $w$. [deskryptywizm rozumiany jako teoria znaczenia]

B. Odniesieniem nazwy własnej w świecie $w$ jest to odniesienie, które jest odniesieniem deskrypcji ustalającej(-ych) odniesienie $\mathrm{w}$ pewnym wyróżnionym świecie $w^{*}$. [deskryptywizm rozumiany jako te oria odniesienia]

Jeśli nazwa własna z n a c zy to samo, co deskrypcja, to jest po prostu synonimiczna $z$ nią i zachowuje się wobec możliwych światów tak, jak zachowuje się deskrypcja - może zmieniać odniesienie i nie jest sztywnym desygnatorem. Jeśli natomiast jakaś niesztywna deskrypcja pełni jedynie funkcję deskrypcji ustalającej odniesienie (Kripke 1980, s. 55), to odniesieniem nazwy jest ten przedmiot, który wyznacza deskrypcja w świecie, w którym posłużono się nią do ustalenia odniesienia. W konsekwencji nazwa odnosi się do tego samego przedmiotu we wszystkich możliwych światach.

Rozróżnienie dwóch sposobów rozumienia tezy 1 ma konsekwencje wobec tezy 2: jeśli koniecznym i wystarczającym kryterium ustalania odniesienia nazwy w dowolnym świecie $w$ jest spełnianie warunku deskryptywnego w jakimśs wybranym świecie $w^{*}$, to od użytkownika, który zna nazwę, wymagane jest jedynie, by znał deskrypcję ustalającą odniesienie w świe- 
cie $w^{*}$. Z tego powodu deskrypcyjnej teorii odniesienia będzie dotyczyła tylko część z zarzutów przedstawionych w argumencie semantycznym (będzie jej jednak w pełni dotyczył zarzut epistemiczny).

Po uwzględnieniu różnych sposobów rozumienia, co może stanowić konieczne i wystarczające kryterium ustalania odniesienia, deskryptywizm w rozumieniu Kripkego może być zdefiniowany następująco:

DESKRYPTYWIZM JAKO TEORIA ZNACZENIA

Z1. Odniesienie nazwy własnej w świecie $w$ jest semantycznie ustalane poprzez spełnianie warunku deskryptywnego jakiejś (jakichś) deskrypcji określonej ustalającej odniesienie nazwy $\mathrm{w}$ świecie $w$.

Z2. Użytkownik zna nazwę własną wtedy i tylko wtedy, gdy zna deskrypcję określoną(-e), która ustala odniesienie nazwy w świecie $w^{3}$.

3 Kripke sformułował deskrypcyjną teorię znaczenia i odniesienia w postaci tez (1)-(6) (1980, s. 71). W tezie (2) mowa jest o przekonaniu użytkownika, w tezie (3) o tym, że owo przekonanie jest prawdziwe. Deskryptywizm jest teorią semantyczną nazw własnych, która postuluje, że odniesienie nazwy jest ustalane poprzez spełnianie warunku deskryptywnego jakichś deskrypcji. Zatem na gruncie deskryptywizmu prawdziwe przekonanie mówiącego jest uzasadnionym przekonaniem, ponieważ deskrypcje są semantycznie związane $\mathrm{z}$ nazwami własnymi. Uzasadnione prawdziwe przekonanie jest klasycznie rozumiane jako wiedza, dlatego w sformułowaniu Z2 i O2 obu wersji deskryptywizmu użyłam sformułowania „zna”. Ze sformułowania Z1 i Z2 teorii znaczenia wynika (1980, s. 73) teza (5) i (6), a ze sformułowania O1 i O2 wynika teza (5). By użytkownikowi było znane odwrócenie tez (5) i (6), o którym mówi Kripke (1980, s. 73), musimy w sformułowaniach Z2 i O2 użyć określenia „wtedy i tylko wtedy". 
O1. Odniesienie nazwy własnej w świecie $w$ jest semantycznie ustalane poprzez spełnianie warunku deskryptywnego jakiejś (jakichś) deskrypcji określonej, ustalającej odniesienie nazwy w pewnym wyróżnionym świecie $w^{*}$.

O2. Użytkownik zna nazwę własną wtedy i tylko wtedy, gdy zna deskrypcję określoną (-e), ustalającą odniesienie nazwy w wyróżnionym świecie $w^{*}$.

Z tez Z1 i Z2 deskryptywnej teorii znaczenia wynika, że jeśli nazwa $n$ jest synonimiczna z deskrypcją $\iota x . \varphi$, to sąd wyrażony przez zdanie: „Jeśli $n$ istnieje, to $n$ jako jedyny jest $\varphi$ ” jest konieczny oraz znany użytkownikowi a priori. Z kolei z tez $\mathrm{O} 1$ i O2 deskryptywnej teorii odniesienia wynika jedynie, że sąd wyrażony przez zdanie: „Jeśli $n$ istnieje, to $n$ jako jedyny jest $\varphi$ " jest prawdziwy w wybranym świecie $w^{*}$ oraz znany użytkownikowi a priori (Kripke 1980, s. 73; owo wynikanie omówię w sekcji I.4 przy odpowiedzi na zarzut epistemiczny).

Współcześnie atak na deskryptywizm został pogłębiony: twierdzenie deskryptywistów, że postrzeganie i rozpoznawanie przedmiotów jest ściśle związane z ich charakteryzacją, jest podważane przez zwolenników teorii bezpośredniego odniesienia (Recanati 2012), których zdaniem przedmioty mogą być nam dane poprzez epistemiczną relację bezpośredniego zaznajomienia (s. 4). Twierdzenie deskryptywistów, że przedmioty są nam dane deskryptywnie, nie musi być jednak rozumiane na sposób mocny, wykluczajacy relacyjne nabywanie wiedzy o cechach przedmiotu (nabywanie wiedzy poprzez doświadczenie percepcyjne). Cechy, o których wiedza jest nabywana relacyjnie, są zazwyczaj wyrażane językowo poprzez deskrypcje z wyrażeniami okazjonalnymi. Pełnienie przez takie deskrypcje funkcji ustalających odniesienie było dopuszczone przez klasycznych deskryptywistów, Russella 
i Strawsona, i nawet Kripke, przedstawiając pogląd deskryptywistów, nie protestował przeciwko traktowaniu deskrypcji z wyrażeniami okazjonalnymi jako ustalających odniesienie (1980, s. 79). Obecność wyrażeń okazjonalnych w deskrypcji spełnia warunki nałożone przez Russella na deskrypcje synonimiczne z nazwami (1917/1951, s. 157). Strawsonowi całkowite pozbycie się wyrażeń okazjonalnych z deskrypcji wydawało się po prostu niemożliwe (1959/1996, s. 182, przypis 1). Co więcej, dla Strawsona deskrypcja z wyrażeniem demonstratywnym mogła być jedyną deskrypcją, którą w ostateczności ktoś mógł podać jako identyfikującą odniesienie nazwy (1959/1996, s. 193). Posługiwanie się wyrażeniami okazjonalnymi z kolei jest niemożliwe bez wykorzystania elementów kontekstu (na przykład przedmiotów) jako środków wyrazu myśli (por. Frege 1891/1979, s. 91-92). Ale nawet taki relacyjny deskryptywizm, który dopuszcza nabywanie wiedzy poprzez doświadczenie percepcyjne, jest współcześnie obiektem ataku (Bochner 2014).

Po Nazywaniu a konieczności deskryptywizm utrzymywać można na kilka sposobów. Przyjęcie tradycyjnego rozumienia znaczenia oznacza akceptację klasycznego sformułowania deskryptywizmu jako tez Z1 i Z2 bądź O1 i O2. Deskrypcyjnymi teoriami, które zakładają te tezy, są: semantyka dla nazw własnych Glüer i Pagina (2006, 2008), deskryptywizm usztywniony (na przykład Searle 1983 oraz Jackson 1998) oraz dwuwymiarowa semantyka Chalmersa $(2006)^{4}$. Jeśli natomiast - tak jak Kripke - odrzuci się semantyczne założenie, że informacja, która jest nam znana i którą posługujemy się do ustalania, o jakie indywiduum chodzi, wyznacza semantycznie odniesienie nazwy, to pojawi się możliwość sformułowania nieklasycznych semantyk deskrypcyjnych, które odróżniają sposób semantycznego wyznaczenia odniesienia od sposobu, którym posługuje-

${ }^{4} \mathrm{Z}$ zastrzeżeniem, że deskrypcje w tej semantyce ustalają odniesienie ze względu tylko na wybrane parametry kontekstu i świata. 
my się w codziennej praktyce językowej. Dla nieklasycznych deskryptywistów to, co znamy i wykorzystujemy do ustalania odniesienia, zawsze jest czymśs zupełnie innym niż semantyczne kryterium ustalania odniesienia: albo wyłacznie w sformułowaniu tezy Z1/O1 jest mowa o deskrypcjach (deskrypcje służą wyłącznie do ustalania odniesienia, ale nie muszą być znane, Kroon 1987), albo wyłącznie w sformułowaniu tezy Z2/O2 (deskrypcje są wykorzystywane przez nas do ustalania, o kogo chodzi w kontekście, ale odniesienie semantyczne jest od deskrypcji niezależne, Jackson 2010, Forbes 1990, Bach 2002, Katz 1994, Justice 2001).

Po wyjaśnieniu kwestii, czym jest deskryptywizm, przejdźmy do omówienia konsekwencji, jakie pociąga za sobą uwzględnienie parametru czasu przy definiowaniu deskryptywizmu.

\section{Uwzględnienie parametru czasu:} wyrażenia „teraz”, „obecny”

Od chwili napisania Nazywania a konieczności minęło ponad czterdzieści lat. Po przełomowych pracach Montague'a, Scotta, Priora, Kampa i Kaplana stało się jasne, że interpretacja niektórych wyrażeń jest zależna nie tylko od parametru możliwego świata, lecz również od innych parametrów, takich jak czas i kontekst. Zagadnienie uwzględnienia dodatkowych parametrów czasu zostało poruszone przez Salmona przy omawianiu pojęcia sztywnego desygnatora: jesteśmy skłonni przyjmować, że sztywny desygnator desygnuje ten sam przedmiot również ze względu na czasy, w których przedmiot nie istnieje (2005, s. 36-41). By intuicyjnie prawdziwe zdanie „Arystoteles jest starożytnym filozofem” było prawdziwe w modelu, konieczne jest, by nazwa desygnowała Arystotelesa również ze względu na obecny czas. Ze względu na parametry czasu Kripkego definicja sztywnego desygnatora została zrewidowana, ale może podobnej rewizji wymaga jego definicja deskryptywizmu? 
Spróbujmy dokonać takiej rewizji. Po dodaniu parametru czasu definicja deskryptywizmu jako teorii znaczenia brzmi:

DESKRYPTYWIZM JAKO TEORIA ZNACZENIA (Z DODANYM PARAMETREM CZASU)

$\mathrm{Z1}_{\mathrm{t}}$ Odniesienie nazwy własnej $\mathrm{w}$ świecie $w$ i czasie $t$ jest semantycznie ustalane poprzez spełnianie warunku deskryptywnego jakiejś (jakichś) deskrypcji określonej, ustalającej odniesienie nazwy w świecie $w$ i czasie $t$.

Z2 $2_{\mathrm{t}}$ Użytkownik zna nazwę własną w czasie $t$ wtedy i tylko wtedy, gdy zna deskrypcję określoną (-e), która ustala odniesienie $\mathrm{w}$ świecie $w$ i czasie $t$.

Sformułowanie takie wydaje się nie budzić kontrowersji, a czasami teza Z1 deskryptywizmu jest podawana właśnie w takiej postaci (Salmon 2005, s. 14-15).

Większą ostrożność należy zachować natomiast przy formułowaniu tez deskrypcyjnej teorii odniesienia. Naturalnym (przynajmniej z technicznego punktu widzenia) rozszerzeniem definicji obu wersji deskryptywizmu byłoby przyjęcie, że istotą odróżnienia deskrypcyjnej teorii znaczenia od deskrypcyjnej teorii odniesienia w zakresie semantycznego mechanizmu ustalania odniesienia jest to, że w deskrypcyjnej teorii znaczenia odniesieniem nazwy $\mathrm{z}$ uwagi na dowolny parametr ewaluacji jest to odniesienie, które ma deskrypcja ustalająca odniesienie z uwagi na ów parametr. Natomiast w deskrypcyjnej teorii odniesienia odniesieniem nazwy ze względu na dowolny parametr ewaluacji jest to odniesienie, które ma deskrypcja ustalająca odniesienie ze względu na wy różni ony parametr ewaluacji. Po dodaniu parametru czasu wyróżnionym parametrem ewaluacji jest para złożona $\mathrm{z}$ wyróżnionego możliwego świata i wyróżnionego czasu, $\left\langle w^{*}, t^{*}\right\rangle$. Niemniej jednak w tezach $\mathrm{O} 1_{\mathrm{t}} \mathrm{i} \mathrm{O} 2_{\mathrm{t}}$, zamiast pary złożonej z wyróżnio- 
nych parametrów świata i czasu, $\left\langle w^{*}, t^{*}\right\rangle$, zasadnym wydaje się mówić o parze złożonej z wyróżnionego świata oraz dow oln e go czasu, $\left\langle w^{*}, t\right\rangle$.

Kwestia zachowania deskrypcji wobec czasu wymaga wyjaśnienia. Przy dodawaniu parametru czasu musimy zadbać o to, by wyrażenia, które nie były deskrypcjami bez tego parametru, nadal nie były deskrypcjami i nie były z deskrypcjami określonymi mylone. Dla przykładu wyrażenie „królowa Anglii” bez parametru czasu może być prawdziwie orzeczone o wielu kobietach, zarówno o Elżbiecie II, jak i o królowej Wiktorii. Po dodaniu parametru czasu wyrażenie to może być prawdziwie orzeczone o jednej osobie (na przykład o królowej Wiktorii ze względu na rok 1860). Ale jeżeli zmieniamy parametr czasu, to wyrażenie to może ze względu na ten sam świat być prawdziwie orzeczone o różnych osobach bądź nie być prawdziwie orzeczone o nikim (na przykład może denotować królową Elżbietę II ze względu na rok 2014 i w ogóle nie denotować ze względu na rok 1950). By wyrażenia takie jak „królowa Anglii” nie stały się automatycznie deskrypcjami, musimy dodać wymóg, by deskrypcje denotowały ze względu na świat $w$ ten sam przedmiot we wszystkich czasach. Wymóg ten spełniaja wyrażenia z czasem usztywnionym bądź za pomoca podania daty („królowa Anglii w roku 2015”), bądź za pomocą wyrażeń okazjonalnych „teraz”, „obecny” („obecna królowa Anglii”)5. Po wyjaśnieniu kwestii zachowania deskrypcji wobec czasu wydaje się zasadnym nie zmieniać parametru czasu z dowolnego na jakiś wyróżniony, ponieważ deskrypcje z definicji denotują ze względu na świat $w$ ten sam obiekt w dowolnym czasie. Możemy zdefiniować tezy deskrypcyjnej teorii odniesienia $\mathrm{z}$ dodanym parametrem czasu w następujący sposób:

5 Por. przykłady podawane przez Russella: „obecny król Francji”, „obecny król Anglii” (Russell 1905, s. 479). 
DESKRYPTYWIZM JAKO TEORIA ODNIESIENIA ( $\mathrm{Z}$ DODANYM PARAMETREM CZASU)

$\mathrm{O} 1_{\mathrm{t}}$ Odniesienie nazwy własnej $\mathrm{w}$ świecie $w$ i czasie $t$ jest semantycznie ustalane poprzez spełnianie warunku deskryptywnego jakiejś (jakichś) deskrypcji określonej ustalającej odniesienie nazwy w pewnym wyróżnionym świecie $w^{*}$ i czasie $t$.

$\mathrm{O} 2$ Użytkownik zna nazwę własną w czasie $t$ wtedy i tylko wtedy, gdy zna deskrypcję określoną(-e), która ustala odniesienie w wyróżnionym świecie $w^{*}$ i czasie $t$.

Zwróćmy uwagę, że usztywnienie parametru czasu w istotny sposób wpływa na kwestię wiedzy, o której jest mowa w tezach Z2 i O2 obu wersji deskryptywizmu: niezależnie od tego, czy z uwagi na wiele światów, czy z uwagi na jeden wyróżniony świat, znajomość warunku deskryptywnego deskrypcji ustalającej odniesienie nazwy będzie wymagana od użytkownika we ws zystkich c z a s a ch, w których użytkownik zna nazwę. Właśnie przeciwko takiej konsekwencji jest skierowany zarzut epistemiczny Kripkego oraz niektóre z wątków argumentu semantycznego.

Zauważmy, że - w odróżnieniu od deskrypcji z parametrem czasu usztywnionym za pomocą daty - wyrażone językowo cechy z wyrażeniami okazjonalnymi „teraz”, „obecny” nie denotują w oderwaniu od kontekstu. Ich denotacja w istotny sposób zależy od kontekstu: cechy wyrażone językowo wymagają uzupełnienia przez kontekst, by składnik tych cech, wyrażenie okazjonalne, otrzymał wartość semantyczną. Więc w odróżnieniu od deskrypcji z datą w przypadku deskrypcji z wyrażeniem okazjonalnym wystarczy znajomość wyrażonej językowo cechy oraz znajomość kontekstu, by znać nazwę. Jeśli deskrypcyjna teoria dopuści te ostatnie deskrypcje jako ustalające odniesienie, to wymóg wiedzy w przypadku deskrypcyjnej teorii odniesienia zostanie znacząco osłabiony, ponieważ, by znać nazwę 
$\mathrm{w}\left\langle w^{*}, t\right\rangle$, wystarczy znać cechę, która wyznacza jeden przedmiot w jakimśs czasie świata $w^{*}$, oraz znać czas (element kontekstu). Osłabienie wymogu wiedzy polega na tym, że użytkownik nie musi dodatkowo wiedzieć, jaka data jest te r a z . Złożenie „cecha $+t$ ” jest hybrydyczne, co przekłada się na sposób, w jaki części tego złożenia mogą być nam znane. Jeśli cechę możemy znać poprzez wyrażenie językowe, to moment czasu $t$ musi być nam dany bezpośrednio. Czas nieustannie zmienia się i co chwila są nam bezpośrednio dane różne jego momenty. Złożenie „cecha $+t$ ” oraz złożenie „cecha $+t$ ” moga wyznaczać różne przedmioty przy założeniu, że $t$ jest różne od $t^{\prime}$ (por. Poller 2008). By znać deskrypcję identyfikującą ten sam przedmiot $\mathrm{w}$ dowolnej bezpośrednio danej chwili, musielibyśmy znać cechę, którą przedmiot spełnia w owej chwili. Moglibyśmy w czasie $t^{\prime}$ próbować odwoływać się do chwili $t$, która minęła, i w złożeniu „cecha $+t$ ” zamieniać jedno wyrażenie okazjonalne na inne po to, by złożenie „cecha $+t$ ” wyznaczało ten sam przedmiot ( $\mathrm{w}$ pewnym sensie dokonywalibyśmy wówczas „kompensującej zmiany sensu”, Frege 1918/1977, s. 111). Ale w języku mamy ograniczoną możliwość takiej zamiany: możemy, w zależności od różnicy w czasie, „dzisiaj” zamienić na „wczoraj”, „przedwczoraj”, „przedprzedwczoraj” - lecz takich zamian może być zaledwie kilka i wymagałyby one wiedzy, iloma przedrostkami „przed-” należy poprzedzić wyrażenie okazjonalne. By znać nazwę, musielibyśmy nie tylko umieć odpowiednio zamieniać wyrażenia okazjonalne, lecz również znać inną cechę. Ponieważ deskrypcje z wyrażeniami okazjonalnymi „teraz”, „obecny” są dopuszczone przez deskryptywizm jako deskrypcje identyfikujące, nie jest wykluczona sytuacja, w której mogą być nam znane wyłącznie takie deskrypcje. W takiej sytuacji, by znać nazwę w dowolnej chwili, musielibyśmy wiedzieć, jakim jest obiekt w tej dowolnej chwili' ${ }^{6}$. Ten wymóg

${ }^{6}$ Musielibyśmy znać to, co Evans (1982, s. 195-196) określa mianem „sposobu ciagłego podtrzymywania kontaktu z obiektem” (,a way of keeping track of an object"). 
wydaje się nierealny - nawet o najbliższych osobach możemy nie wiedzieć, jakie cechy mają w tej chwili. Dlatego - by utrzymać zdroworozsądkowy deskryptywizm - wydaje się sensownym osłabienie wymogu wiedzy: by znać nazwę w chwili $t$, wystarczy znać w jakimśs momencie (w $t^{\prime}$ ) deskrypcję ustalającą odniesienie nazwy.

Osłabienie wymogu wiedzy ma jednak swoją cenę, a mianowicie wymóg znajomości kontekstu. Z powodu wymogu znajomości kontekstu (znajomości któregoś z jego elementów, na przykład takich jak moment czasowy lub miejsce) taka deskrypcję można znać, jedynie ws półd zieląc z kimś, kto ustala odniesienie nazwy za pomocą deskrypcji z wyrażeniem okazjonalnym, ten sam moment czasowy, miejsce. Ten wymóg sam w sobie jest bardzo mocny: jego akceptacja oznacza, że jedynie nieliczni użytkownicy języka, którzy współdzielili z ustalającym odniesienie ten sam element kontekstu, moga znać deskrypcję ustalającą odniesienie i w konsekwencji znać nazwę. Jeśli poważnie potraktować wymóg $\mathrm{O} 2_{\mathrm{t}}-$ znajomości deskrypcji ustalającej odniesienie - to przy dopuszczeniu deskrypcji z wyrażeniami okazjonalnymi jako ustalajacych odniesienie ten wymóg nie może być spełniony przez większość użytkowników języka. Dla przykładu: jeśli rodzice Arystotelesa nadali mu imię za pomocą deskrypcji „nasz syn”, to jedynie nieliczne grono osób (ci, którzy znali rodziców Arystotelesa i wiedzieli, do kogo odnosi się wyrażenie „nasz”) mogłoby znać nazwę „Arystoteles” (por. Strawson 1959/1996, s. 182, przypis 1).

Z powyższych powodów, po dodaniu parametru czasu oraz dopuszczeniu deskrypcji z wyrażeniami okazjonalnymi jako ustalających odniesienie, teza $\mathrm{O} 2_{\mathrm{t}}$ intuicyjnie wymaga kolejnej rewizji - zamiany wymogu znajomości deskrypcji ustalają cej odniesienie $\iota x . \varphi$ na wymóg znajomości deskrypcji identy fikującej $\iota x . \psi$, czyli takiej, która wyznacza ten sam obiekt $\mathrm{w}$ świecie $w^{*}, \mathrm{w}$ którym posłużono się deskrypcją $\iota x . \varphi$ 
do ustalania odniesienia nazwy ${ }^{7}$. W ten oto sposób dochodzimy do założeń deskrypcyjnej teorii odniesienia, która będzie broniona w tym artykule:

BRONIONA DESKRYPCYJNA TEORIA ODNIESIENIA (Z OSŁABIONYM WYMOGIEM WIEDZY)

$\mathrm{O} 1_{\mathrm{OP}}$ Odniesienie nazwy własnej $\mathrm{w}$ świecie $w$ i czasie $t$ jest semantycznie ustalane poprzez spełnianie warunku deskryptywnego jakiejś deskrypcji określonej $\iota x . \varphi$ ustalającej odniesienie nazwy w pewnym wyróżnionym świecie $w^{*}$ i czasie $t$;

$\mathrm{O} 2_{\mathrm{OP}}$ Użytkownik zna nazwę własną w czasie $t$ wtedy i tylko wtedy, gdy zna w jakimś czasie $t^{\prime}$ dowolną deskrypcje $\iota x . \psi$, która w wyróżnionym świecie $w^{*}$ wyznacza ten sam obiekt, co deskrypcja ustalająca odniesienie nazwy,

przy czym $\varphi$ i $\psi$ zawierają dokładnie jeden i ten sam predykat „nazywany $\alpha$ ”, gdzie „ $\alpha$ ” jest napisem bądź dźwiękiem ${ }^{8}$.

$\mathrm{W}$ następnych rozdziałach pokażę, w jaki sposób deskrypcyjną teorię odniesienia w powyższym sformułowaniu można obronić przed zarzutami Kripkego. Zacznę od wytłumaczenia, w jaki sposób realizowana jest teza $\mathrm{O}_{\mathrm{OP}}$. Spośród dwóch tez deskryptywizmu tylko ona jest tezą semantyczną (teza $\mathrm{O} 2_{\mathrm{OP}}$ jest tezą pragmatyczną), w związku z czym od sposobu jej realizacji zależy odpowiedź na zarzuty dotyczące warunków prawdziwości zdań z nazwami własnymi.

7 Donnellan (1977, s. 17) opisuje możliwe rozumienie deskryptywizmu, w którym deskrypcja ustalająca odniesienie jest jedną ze zbioru deskrypcji związanych z nazwą.

8 Dla uproszczenia wszędzie dalej będę podawała definicję bronionej wersji deskryptywizmu (tezy $\mathrm{O} 1_{\mathrm{OP}} \mathrm{i} O 2_{\mathrm{OP}}$ ) w wersji skróconej, bez wymieniania wymogu syntaktycznego (ów wymóg będzie domyślny). Przez „dźwięk” rozumiem tu typ dźwięku (fonem). 


\section{Konstruowanie formalnych odpowiedników nazw zgodnie z teza $O 1_{O P}$}

Jak zaznaczyłam w poprzedniej sekcji, w deskryptywizmie rozumianym jako teoria odniesienia nazwy własne są sztywnymi desygnatorami $\mathrm{z}$ definicji (w związku z czym tej wersji deskryptywizmu nie dotyczy modalny zarzut Kripkego). W (Poller 2014) przedstawiłam sposób formalnej reprezentacji nazw własnych zgodny z tezą $\mathrm{O} 1_{\mathrm{OP}}$ deskrypcyjnej teorii odniesienia oraz podałam dowód, że nowe termy, które są formalnymi odpowiednikami nazw (na ich określenie używam terminu „termy nazwowe”), faktycznie są sztywnymi desygnatorami $\mathrm{w}$ mocnym rozumieniu, czyli desygnują ten sam obiekt we wszystkich światach i czasach, niezależnie od tego, czy obiekt istnieje w tych światach i czasach. Pominę zatem dokładny opis sposobu konstruowania formalnych odpowiedników nazw własnych i przedstawię poniżej jedynie jego kluczowe elementy. Główna idea deskrypcyjnej teorii odniesienia jest następująca: nazwy są termami semantycznie złożonymi, które otrzymują odniesienie poprzez deskrypcje określone prawdziwe o obiekcie odniesienia. Deskrypcje z kolei są termami, których interpretacja zależy od interpretacji predykatów. Nazwy są bardziej złożone semantycznie niż deskrypcje - ich interpretacja zależy od interpretacji deskrypcji określonych i ostatecznie od interpretacji predykatów. W formalnej reprezentacji odwzorowującej tę ideę deskrypcyjnej teorii odniesienia nazwy i deskrypcje są symbolami, których interpretacja jest zależna od interpretacji semantycznie prostych symboli - stałych predykatywnych i zmiennych.

Konstruowanie formalnych odpowiedników nazw (termów nazwowych) zaczęłam od rozważania języka pierwszego rzędu $\mathcal{L}$ zawierającego zbiór wyróżnionych predykatów $\left(N_{1}, N_{2}\right.$, $N_{3}, \ldots$ ) odczytywanych „nazywany $\alpha$ ”, ,nazywany $\beta$ ”, gdzie przez , $\alpha$ ” i „ $\beta$ ” rozumiane są ciągi dźwięków bądź napisów. $\mathrm{W}$ modelach zamierzonych (w uniwersach których istnieje spo- 
łeczność językowa) owa społeczność posługuje się elementami uniwersum (dźwiękami, napisami) na wyróżnienie innych elementów uniwersum. Jedynymi termami, które zawiera język $\mathcal{L}$, są zmienne i deskrypcje określone (język $\mathcal{L}$ pełni funkcję pomocniczą, by później przejść do rozważania docelowego języka $\mathcal{L}^{+}$zawierającego termy nazwowe, $\mathcal{L} \subset \mathcal{L}^{+}$). Przez deskrypcje określone rozumiem $\iota$-termy postaci $\iota x .\left[{ }_{i}\right] \varphi$ (gdzie "[i]" jest wariantem notacyjnym operatora czasu wtedy („prawda $\mathrm{w} t_{i}$ ”) przyjętym za Rini \& Cresswell (2012), które z uwagi na dowolny świat $w$ i czas $t$ denotuja ten przedmiot, który denotuje term $\iota x . \varphi$ z uwagi na świat $w$ i czas $t_{i}$ $\left(I_{\langle w, t\rangle}^{g}\left(\iota x .\left[_{i}\right] \varphi\right)=I_{\left\langle w, t_{i}\right\rangle}^{g}(\iota x . \varphi)\right)$. Deskrypcje $\iota x .\left[{ }_{i}\right] \varphi$ nazywam ,aktualnymi ze względu na czas ewaluacji $t_{i}$ " (albo po prostu „aktualnymi”, gdy jest jasne z kontekstu, ze względu na jaki moment czasowy są one aktualne).

Idea, która stoi za konstruowaniem formalnych odpowiedników nazw, desygnujących poprzez deskrypcje, jest dość prosta i polega na wykorzystywaniu podziału zbioru deskrypcji przez relację równoważności. Technicznie sprawa nieco się komplikuje, ponieważ dochodzi parametr świata, który należy uwzględnić (deskrypcje denotują niesztywnie). Dlatego do zbioru, na którym wykonuję podziały, należą nie same deskrypcje, lecz pary uporządkowane, złożone z deskrypcji oraz świata, w którym deskrypcja denotuje. Deskrypcje języka $\mathcal{L}$, które wykorzystuję do zdefiniowania termów nazwowych języka $\mathcal{L}^{+}$, mają postać ! $\left.x .{ }_{i}\right]\left(N_{j}(x) \wedge Q(x)\right)$, czyli postać $\iota$-termów niezawierających wolnych wystąpień zmiennych, w których „ $N_{j}$ ” jest dowolnym wyróżnionym predykatem, a "Q" jest dowolnym jednoargumentowym niewyróżnionym predykatem (np. „(obecny) prezydent nazywany [tramp]”). Termy nazwowe denotują poprzez klasy podziału zbioru par deskrypcja-świat, w których to klasach znajdują się pary uporządkowane, takie których deskrypcje denotuja ten sam obiekt oraz zawieraja ten sam wyróżniony predykat $N_{j}$. Dla przykładu rozważmy dwie deskrypcje, „planeta nazywana [fosforus]”, „planeta na- 
zywana [hesperus]" (na oznaczenie pierwszej deskrypcji będę używała symbolu „ $\gamma_{1}$, a na oznaczenie drugiej symbolu „ $\gamma_{2}$ "). Obie deskrypcje denotują w naszym świecie, lecz pary $\left\langle\gamma_{1}, w\right\rangle$, $\left\langle\gamma_{2}, w\right\rangle$ będą należały do różnych klas podziału, ponieważ $\gamma_{1}$ zawiera predykat „nazywany [fosforus]”, podczas gdy $\gamma_{2}$ zawiera inny predykat: „nazywany [hesperus]”. By zdefiniować interpretację dowolnego termu $n_{i}$, potrzebuję dwóch funkcji - jednej, która łączy term $n_{i}$ z klasą podziału, i drugiej, która klasie podziału przypisuje ten sam obiekt denotowany przez dowolną deskrypcję pary deskrypcja-świat owej klasy.

$\mathrm{W}$ efekcie uzyskuję termy, które nie są synonimiczne $\mathrm{z}$ deskrypcjami, lecz są sztywnymi desygnatorami w najmocniejszym rozumieniu - desygnują ten sam obiekt we wszystkich światach i czasach. Sądy identycznościowe wyrażone poprzez zdania z koreferencyjnymi termami są koniecznie prawdziwe, a warunki prawdziwości dla zdań z termami nazwowymi i operatorami modalnymi pozostają takie same bez względu na to, w jakim zasięgu term nazwowy znajduje się względem operatora (por. Poller 2014). Taka formalna reprezentacja nazw własnych pozwala połączyć różne koreferencyjne nazwy ze zbiorami różnych deskrypcji, co można wykorzystać przy rozwiązywaniu łamigłówek z nazwami własnymi (Poller 2016). Przejdę teraz do podania argumentacji, że broniona wersja deskrypcyjnej teorii odniesienia jest odporna na epistemiczny zarzut Kripkego.

\section{Odpowiedź na zarzut epistemiczny Kripkego}

Zarzut epistemiczny dotyczy deskryptywizmu w obu wersjach - zarówno deskryptywizmu jako teorii znaczenia, jak i deskryptywizmu jako teorii ustalania odniesienia - i niektórzy twierdzą, że jest on z tego powodu ważniejszy niż zarzut modalny (Jeshion 2002). Teza (5) Kripkego brzmi: „Mówiący zna a priori stwierdzenie: «Jeśli $\mathrm{X}$ istnieje, to $\mathrm{X}$ ma większość spośród własności $\varphi$ ” (Kripke 1980, s. 71). Zdaniem Kripkego teza ta ma swoje odwrócenie również znane mówiące- 
mu a priori: „Prawdą będzie również na gruncie tej teorii, że pewne odwrócenia tego stwierdzenia również a priori uchodzą dla mówiącego za prawdziwe, a mianowicie, jeśli jakaś jedyna rzecz ma większość, we właściwie wyważonym sensie, spośród własności $\varphi$, rzecz ta jest X" (Kripke 1980, s. 73). W tezie (5) jest mowa o istnieniu przedmiotu, który jest odniesieniem nazwy $X$, w odwróceniu tezy (5') chodzi o denotowanie deskrypcji $\iota x . \varphi$. By w ogóle można było mówić, że teza (5') jest odwróceniem (5), musimy założyć, że w obu tezach powinno chodzić albo o istnienie przedmiotu, który jest odniesieniem deskrypcji i nazwy, albo o denotowanie deskrypcji i nazwy 9 .

Rozważmy odczytanie, w którym jest mowa o denotowaniu deskrypcji i nazwy. Niech $n$ będzie dowolną nazwą, ıy. $\varphi$ dowolną deskrypcją ustalającą odniesienie $n$, a $b$ - dowolnym podmiotem. Przy takim odczytaniu tezy (5) i (5') brzmia:

(5) $b$ wie $a$ priori: [Jeśli $n$ istnieje, to $n$ jako jedyny jest $\varphi$ ]

(5') $b$ wie a priori: [Jeśli $\iota y . \varphi$ istnieje, to $\iota y . \varphi=n$ ]

Jak działa zarzut epistemiczny? Rozważmy najpierw deskrypcyjną teorię znaczenia, która jest zdefiniowana przez dwie tezy Z1 i Z2. Niech (5[ ]) oznacza zdanie w kwadratowych nawia-

${ }_{9}^{9}$ Zazwyczaj przy streszczeniu tego zarzutu mowa jest o modelach ze stałą dziedziną, w których nie ma różnicy między desygnowaniem termu a istnieniem desygnatu termu. Ponieważ $\mathrm{w}$ formalizmie, którego używam (Poller 2014), są zmienne dziedziny i występuje różnica między desygnowaniem termu a aktualnym istnieniem desygnatu (term może desygnować, mimo że przedmiot, który jest jego odniesieniem, nie istnieje w aktualnej dziedzinie), musimy tę kwestię uściślić. Dla deskryptywistów łatwiej jest obronić się przed zarzutem epistemicznym, którego tezy (5) i (5') mówią o istnieniu denotatów deskrypcji i nazw. By nie trywializować epistemicznego zarzutu Kripkego, rozważymy ten zarzut w sformułowaniu mówiącym o wiedzy o desygnowaniu. (Por. Fitting \& Mendelsohn, 1998, s. 230, 236). Na potrzeby zarzutu epistemicznego kripkowskie wyrażenia "denotuje”, „istnieje” będę oddawała za pomocą jednego wyrażenia „istnieje” („Jeśli pierwszy kosmonauta istnieje...”), lecz rozumieć go będę jako denotowanie. 
sach z (5), a (5' [ ]) zdanie z (5'). By nie trywializować zarzutu, zakładamy, że użytkownik zna nazwę własną $n$. Oznacza to (na mocy Z2), że zna deskrypcję określoną ıy. $\varphi$. Deskrypcja ta jest znaczeniem nazwy $n$ i z tego powodu możemy w zdaniach (5[ ] ) i (5'[ ]) zamienić nazwę na deskrypcję. Zdania uzyskane z (5[ ]) i (5'[ ]) są analitycznie prawdziwe. Tym samym, jeśli tylko $b$ zna nazwę w możliwym świecie $w$, to nie może nie wiedzieć w owym możliwym świecie, że (5[ ]) i (5'[ ]). Wiedza $b$ jest aprioryczna, uzyskana jedynie na mocy znaczenia. Zatem z tezy Z2 deskryptywizmu wynikają tezy (5) i (5') (Kripke, 1980, s. 73).

Rozważmy teraz, jak tezy (5) i (5') wynikają z deskrypcyjnej teorii odniesienia. Jest ona zdefiniowana przez dwie tezy: O1 i O2. Deskrypcja ustalająca odniesienie $\iota y . \varphi$ jest niesztywna, i zdania (5[ ] ) i (5'[ ]) są prawdziwe w wyróżnionym (aktualnym) świecie $w^{*}$, natomiast $w$ innym świecie mogą być fałszywe. Z tego powodu deskrypcyjnej teorii odniesienia nie dotycza wszystkie argumenty z możliwej niewiedzy: gdyby Gödel nie był autorem dowodu niezupełności arytmetyki, to moglibyśmy nie wiedzieć, że jest. Wiedza, o której mowa w deskrypcyjnej teorii odniesienia, dotyczy wyłącznie naszego świata. Znów, by nie trywializować zarzutu, zakładamy, że użytkownik $b$ zna nazwę własną $n$. Oznacza to (na mocy O2), że $b$ zna deskrypcję ıy. $\varphi$. Deskrypcja ta jest deskrypcją ustalającą odniesienie i nie musi być znaczeniem nazwy $n$. Z tego powodu w zdaniach (5[ ] i (5'[ ]) nie da się zamienić nazwy na tę deskrypcję. Jeśli $b$ zna deskrypcję, to wie, że przedmiot, który ona denotuje $\mathrm{w}$ wyróżnionym świecie $w^{*}$, jest odniesieniem nazwy.

Zanim rozważymy, w jakiej formie zarzut epistemiczny będzie stosował się do bronionej teorii deskrypcyjnej uwzględniającej czas, ważne jest zrozumienie, w jaki sposób Kripke argumentował, że jednak nie mamy wiedzy a priori. Tezy (5) i (5') wynikają z tez Z2 i O2 obu wersji deskryptywizmu, które zawierają określenie „wtedy i tylko wtedy”. Zatem do obalenia (5) i (5') wystarczyło pokazać, że można znać nazwę 
mimo braku znajomości jakichkolwiek deskrypcji (argument z ignorancji) oraz mimo posiadania wyłącznie fałszywych deskrypcji.

Broniona teoria deskrypcyjna dopuszcza jako deskrypcje ustalające odniesienie deskrypcje z wyrażeniami okazjonalnymi. Deskrypcje takie wymagają uzupełnienia przez element kontekstu, którym jest na przykład moment czasu. By użytkownik mógł znać taką deskrypcję, musi mieć znajomość elementów kontekstu (na przykład danego momentu czasu). Gdyby w tezie $\mathrm{O} 2_{\mathrm{OP}}$ była wymagana znajomość deskrypcji ustalającej odniesienie, to znać nazwę mogliby tylko ci nieliczni użytkownicy, którzy współdzielili moment czasu z osobą, która ustaliła odniesienie za pomocą deskrypcji z wyrażeniem okazjonalnym. Z tego powodu zamiast wymogu znajomości deskrypcji ustalającej odniesienie w sformułowaniu tezy $\mathrm{O} 2{ }_{\mathrm{OP}}$ jest jedynie wymóg znajomości deskrypcji, która wyznacza ten sam obiekt, co deskrypcja ustalająca odniesienie.

Tezy (5) i (5') po dodaniu parametru czasu mają następującą postać:

$(5)^{\mathrm{t}} \quad b$ wie $a$ priori w $t$ : [Jeśli $n$ istnieje, to $n$ jako jedyny jest $\varphi$ ]

$\left(5^{\prime}\right)^{\mathrm{t}} \quad b$ wie a priori $\mathrm{w} t$ : [Jeśli ! y. $\varphi$ istnieje, to ! $y \cdot \varphi=n$ ]

Ponieważ czas $t$, gdy ktoś zna nazwę, może być różny od $t^{\prime}$ (czasu, gdy zna deskrypcję), to broniona teoria dopuszcza, by ktoś mógł zapomnieć deskrypcję, którą kiedyś znał, a mimo to mógł nadal posługiwać się nazwą. Gdyby Leverrier w dwadzieścia lat po chrzcie Neptuna zapomniał, z jakiego powodu nazwał „Neptunem” planetę Neptun, to nadal mógłby używać nazwy „Neptun” i odnosić się do Neptuna. My, którzy uczymy się nazwy „Neptun”, na mocy tezy $\mathrm{O} 2_{\mathrm{OP}}$ w ogóle nie musimy znać deskrypcji, za pomocą której Leverrier ustalił odniesienie nazwy. Zatem nie dla wszystkich momentów czasu $t$ różnych od $t^{\prime}$ jest tak, że $(5)^{\mathrm{t}} \mathrm{i}\left(5^{\prime}\right)^{\mathrm{t}}$ wynikają z $\mathrm{O} 2_{\mathrm{OP}}$. 
Załóżmy, że my, którzy nauczyliśmy się nazwy „Neptun”, dowiadujemy się w jakimś czasie $t$, że Neptun jest planetą, która zakłóca ruchy innych planet (zaczyna być nam znana $\mathrm{w}$ czasie $t$ deskrypcja ustalająca odniesienie). Jesteśmy prawdziwie przekonani, że (5[ ]) i (5'[ ]) - na gruncie deskrypcyjnej teorii odniesienia mamy więc wiedzę, że (5[ ]) i (5'[ ]). Czy nasza wiedza jest wiedzą a priori? Zdania (5[ ]) i (5'[ ]) nie są analityczne, ponieważ deskrypcja ustalająca odniesienie nie stanowi znaczenia nazwy. Od chwili, w której deskrypcja jest nam znana, te zdania mogą brzmieć dla nas trywialnie, ponieważ nie wnoszą żadnej nowej informacji. Tym niemniej zdania (5[ ] i i (5' [ ]), mimo że zawierają deskrypcję ustalającą odniesienie, nie są nam znane a priori, ponieważ dowiedzieliśmy się o prawdziwości (5[ ]) i (5'[ ]) nie poprzez stypulację. Jedynie w przypadku ustalania odniesienia nazwy $(5[$ [ ] i (5' [ ]) będą nam znane $a$ priori, ponieważ w tym przypadku jest ustalane, do czego odnosi się nazwa (stypulacja), lecz zarzut epistemiczny nie jest skierowany przeciwko takiemu przypadkowi (Kripke 1980, s. 78). W drugiej części artykułu, odpowiadając na argument semantyczny, będę dowodzić, że dwoma momentami, w których ten, kto zna nazwę, musi znać deskrypcje ustalające odniesienie, jest moment chrztu oraz moment uczenia się nazwy. Jeśli rozszerzyć zarzut epistemiczny i rozważyć przypadki osób innych niż osoba dokonująca chrztu, to tezy $(5)^{\mathrm{t}}$ i (5') ${ }^{t}$ będą wynikały z $\mathrm{O} 1_{\mathrm{OP}}$ i $\mathrm{O} 2_{\mathrm{OP}}$ jedynie w momentach uczenia się nazwy. Konsekwencja ta nie wydaje się jednak kontrowersyjna.

W drugiej części artykułu (w następnym numerze) odpowiem na argumenty semantyczne Kripkego oraz rozważę, czy broniona wersja deskryptywizmu ma zalety tradycyjnie przypisywane teoriom deskrypcyjnym. 


\section{Podziękowania}

Jestem szczególnie wdzięczna dr hab. Katarzynie Kijani-Placek za wsparcie i lata dyskusji, które zaowocowały tym tekstem. Wiele wątków artykułu zostało zainspirowanych cennymi uwagami pani doktor. Chciałabym również podziękować profesorowi Tomaszowi Plackowi, dr. hab. Adamowi Olszewskiemu oraz moim kolegom z Zakładu Epistemologii Instytutu Filozofii, a w szczególności Leszkowi Wrońskiemu, Jackowi Wawerowi, Mai (Sherlock) Białek i Juliuszowi Doboszewskiemu za krytykę i cenne wskazówki. Niektóre wątki tekstu zostały przedstawione na zebraniach Zakładu Epistemologii (w latach 2011 i 2012) i chciałabym podziękować wszystkim obecnym wówczas słuchaczom, a w szczególności profesorowi Janowi Woleńskiemu, za cenne komentarze. Podziękowania kieruję również do anonimowych recenzentów.

Badania przedstawione $\mathrm{w}$ tym artykule zostały sfinansowane ze środków Narodowego Centrum Nauki przyznanych na podstawie decyzji numer DEC-2012/05/N/HS1/01429.

\section{Bibliografia:}

Bach, Kent, 2002, Giorgione Was so-called Because of His Name, „Philosophical Perspectives”, nr 16, s. 73-102.

Bochner, Gregory, 2014, The Anti-Individualist Revolution in the Philosophy of Language, „Linguistics and Philosophy”, nr 37, s. 91-120.

Burge, Tyler, 1977, Belief De Re, „The Journal of Philosophy”, nr 74(6), s. 338-362.

Chalmers, David, 2006, The Foundations of Two-Dimensional Semantics, w: Two-Dimensional Semantics, red. Manuel García-Carpintero i Josep Maciá, Oxford University Press, Oxford, s. 55-140.

Cumming, Sam, 2012, Names, w: The Stanford Encyclopedia of Philosophy, red. Edward N. Zalta, plato.stanford.edu/archives/ spr2012/entries/names/ 
Donnellan, Keith S., 1977, The Contingent A priori and Rigid Designators, „Midwest Studies in Philosophy”, II, s. 12-27.

Evans, Gareth, 1973/1996, The Causal Theory of Names, w: The Philosophy of Language, red. Aloysius Patrick Martinich, Oxford University Press, New York, s. 270-283.

Fitting, Melvin; Mendelsohn, Richard, 1998, First-Order Modal Logic, Kluwer Academic Publishers, Dordrecht.

Forbes, Graeme, 1990, The Indispensability of Sinn, „The Philosophical Review", nr 99(4), s. 535-563.

Frege, Gottlob, 1918/1977, Myśl. Studium logiczne, w: tegoż, Pisma semantyczne, przeł. Bogusław Wolniewicz, PWN, Warszawa, s. 101-129.

Glüer, Kathrin; Pagin, Peter, 2006, Proper Names and Relational Modality, „Linguistics and Philosophy”, nr 29(5), s. 507-535.

Glüer, Kathrin; Pagin, Peter, 2008, Relational Modality, „Journal of Logic, Language and Information", nr 17, s. 307-322.

Jackson, Frank, 1998, Reference and Description Revisited, „Noûs”, $\mathrm{nr} 32$ (suplement: „Philosophical Perspectives”, nr 12, Language, Mind, and Ontology), s. 201-218.

Jackson, Frank, 2010, Language, Names and Information, Wiley Blackwell, Singapore.

Jeshion, Robin, 2002, The Epistemological Argument Against Descriptivism, „Philosophy and Phenomenological Research”, $\mathrm{nr} \operatorname{LXIV}(2)$, s. 325-345.

Justice, John, 2001, On Sense and Reflexivity, „The Journal of Philosophy", nr 98(7), s. 351-364.

Katz, Jerrold, 1994, Names Without Bearers, „The Philosophical Review", nr 103(1), s. 1-39.

Kripke, Saul, 1980, Naming and Necessity, Harvard University Press, Cambridge, Massachusetts. Polskie tłumaczenie jako: Kripke, 2001.

Kripke, Saul, 2001, Nazywanie a konieczność, przeł. Bohdan Chwedeńczuk, Fundacja Aletheia, Warszawa.

Kroon, Frederick, 1987, Causal Descriptivism, „Australasian Journal of Philosophy", nr 65(1), s. 1-17.

Poller, Olga, 2008, Wyrażenia okazjonalne jako wyrażenia funkcyjne w semantyce Gottloba Fregego, „Diametros”, nr 17, s. 1-29. [opublikowane pod nazwiskiem „Kukushkina, Volha”]

Poller, Olga, 2014, Formal Representation of Proper Names in Accordance with a Descriptive Theory of Reference, „Polish Journal of Philosophy", nr VIII(1), s. 37-52. 
Poller, Olga, 2016, All the Superhero's Names, „Studia Semiotyczne", $\operatorname{nr} \mathrm{XXX}(2)$, s. 11-44.

Poller, Olga, 2017, Descriptive Content of Names as Predicate Modifiers, „Philosophical Studies”, nr 174(9), s. 2329-2360.

Recanati, François, 2012, Mental Files, Oxford University Press, Oxford.

Rini, Adriane i Cresswell, Maxwell, 2012, The World-Time Parallel: Tense and Modality in Logic and Metaphysics, Cambridge University Press, New York.

Russell, Bertrand, 1905, On Denoting, „Mind”, nr 14(56), s. 479-493.

Russell, Bertrand, 1917/1951, Knowledge by Acquaintance and Knowledge by Description, w: tegoż, Mysticism and Logic, Barnes \& Noble Books, Totowa, New Jersey, s. 152-167.

Salmon, Nathan, 2005, Reference and Essence, Prometheus Books, New York.

Schroeter, Laura, 2012, Two-Dimensional Semantics, w: The Stanford Encyclopedia of Philosophy, red. Edward N. Zalta, plato. stanford.edu/archives/win2012/entries/two-dimensional-semantics/

Searle, John, 1983, Intentionality, Cambridge University Press, New York.

Soames, Scott, 2002, Beyond Rigidity. The Unified Semantic Agenda of Naming and Necessity, Oxford University Press, Oxford.

Strawson, Peter, 1959/1996, Individuals. An Essay in Descriptive Metaphysics, Routledge, New York.

Dr Olga Poller

Instytut Filozofii

Uniwersytet Jagielloński

kukuxa@gmail.com 